\title{
Compatibility of Trichoderma isolates to chlorothalonil fungicide for
}

\section{Integrated diseases Management}

\author{
Mohamed. E. Selim¹; R. A. Bakr'1 ; M. Z. El-shennawy' ${ }^{1}$ and Gamal, A. Ahmed ${ }^{2}$ \\ ${ }^{1}$ Plant Pathology Branch, Department of Agricultural Botany, Faculty of Agriculture, University of Menoufia, Egypt \\ ${ }^{2}$ Plant Pathol. Dept., Fac. Agric., Moshtohor, Benha University. Egypt.
}

\begin{abstract}
:
Fungicides were used successfully for management of different plant diseases worldwide. According to the different human and environmental concerns using of fungicides were mandatory limited. Integration between bio-control agent (Trichoderma) and fungicides was important options. For most effective potential, it is preferred that bio-control agent was tolerant or compatible with the desired used fungicide. In this study, sensitivity of 11 different Trichoderma isolates toward different concentrations of chlorothalonil fungicide compared with Fusarium culmorum and acquisition resistance potential of these isolates toward chlorothalonil were measured. Results showed that all tested Trichoderma isolates positively inhibited $F$. culmorum mycelium growth in vitro. obtained results cleared that both of Trichoderma isolates and $F$. culmorum were sensitive and no tolerance potential against chlorothalonil was recorded. After using adaptation technique results showed that tolerance potential of all tested Trichoderma isolates toward chlorothalonil was significantly increased. Thus, Acquisition of Trichoderma resistance potential toward chlorothalonil can be used for integrated diseases management.
\end{abstract}

KEY WORDS: Fungicides , Biological control, Trichoderma, Chlorothalonil INTRODUCTION:

Approximately 50,000 species of plant pathogens cause an estimated of a $13 \%$ loss Worldwide (Pimentel, 2009). Different organic and non-organic compounds are used all over the world to protect important crop plantation from invasion of hazardous pests and parasites. Chlorothalonil (2,4,5,6-tetrachloroisophthalonitrile) is considered one of the most wide spectrum and non-selective fungicides which is in a wide use in agricultural practices and management protocols to control plant pathogenic fungi. In 1955, Chlorothalonil was registered for the first time in United States and within the next two decades became the third most used fungicide after sulfur and cupper (Gianessi and Marcelli, 2000). During the period from 1990 to 1996, it was estimated that more than 6.8 million $\mathrm{kg}$ of chlorothalonil were used annually only in United States (US EPA 1999). Chlorothalonil is belonging to organochlorine pesticides (OCPs) compounds which are used generally to control different plant diseases including mold, mildew, root rot and other various fungal diseases (US EPA, 1999). The wide use of these compounds (OCPs) had attracted the attention of scientists and biologists especially regarding to environmental concerns may be due to it is ability to persist in soils for decades (Hussen $\boldsymbol{e t}$ al., 2007; Kumar et al., 2011). Moreover, recent studies (Behfar et al., 2013; Nakata et al., 2002) demonstrated that organochlorine pesticides affecting negatively not only environment conditions but also human health. On the other hand, Trichoderma genus was known as one of the most predominant mutualistic biocontrol agents that used in most of organic agriculture systems. Vinale et al., (2007) reported that Trichoderma species are the most frequent isolated fungi from plant root ecosystem. The backlog accumulation of fungicides and many pesticides in the soil increases the risk of deleterious effects on many organisms present in this ecosystem as well as on biological 
processes (Devashree $\boldsymbol{e t}$ al.,2014). It is a great worthy to mention that Trichoderma tangled in many soil-forming processes and many soil functions like organic matter transformation, stabilization of soil aggregates and the circulation of elements play an important role in maintaining adequate soil fertility.

Chlorothalonil is one of the utmost universally used fungicides. This is a synthetic fungicide belong to chlorinated benzonitriles. It was originally registered in the United States of America in 1966. The mode of actions of Chlorothalonil is through the inhibition of cellular enzymes responsible for respiration in the fungal cells (Shi et al., 2011). Chlorothalonil is highly efficient in protecting many host plants against certain fungal diseases caused mainly by Phytophthora infestans and Alternaria solani and prevents the germination of many fungal spores (Leitão et al., 2014). It is highly toxic to many aquatic organisms including fish, and many invertebrates, countless birds, and moreover to human being as well. Chlorothalonil can cause inflammation of the skin as well as eyes and trigger off many gastrointestinal disorders (Wang et al., 2011). Additionally, chlorothalonil is also counted a carcinogen worldwide (Wang $\boldsymbol{e t}$ al., 2011). Moreover, Leitão et al., (2014) stated that the half-life of chlorothalonil is reached up to three months in many soils under laboratory conditions, whilst in the field conditions it reaches up to 70 days. It is true that the decomposition of chlorothalonil in the soil is a very complicated process through the fungal and bacterial bioremediation and this can happen in the soil up to 30 days. Moreover, the continual usages of chlorothalonil in many field crops worldwide, it can be detected in the soil for three months till 1 year (Chaves et al., 2008). Furthermore, chlorothalonil residues are frequently detected in many field crops, and many vegetables and fruits worldwide (Chaudhuri et al., 2013).

Recently 89 species belonging to anamorph stage of Trichoderma fungus were identified (Samuels, 2006). Trichoderma as bio control agents have been developed for different commercial products for plant pathogen control (Woo et al., 2014). The predominate of these kinds of beneficial organisms along with their high potential as innovative and premium bio-control agents (Hewedy et al.,2020) led to depending on them not only in organic agriculture where no chemical pesticides compounds can apply but also in most of integrated pest management (IPM) techniques to protect economic plants from infection of pathogenic microorganisms. In such these protocols combination between chemical pesticide and bio-control agents are used to reduce pesticide applications. Several previous studies demonstrated the integration between bio- control agents and fungicides in plant disease control. (Eisa and El-Feky, 2014; Hu et al., 2016; Ons et al., 2020). So that, selecting resistant races of bio-control agents against wide use chemical pesticides gains special importance to avoid adverse effects on successful of biological control process.

The objectives of the present study is aiming to (i)Testing sensitivity of 11 different Trichoderma isolates belonging to the four different species i.e., Trichoderma harzianum, $T$. hamatum, $T$. viridi and T. koningii toward different concentrations of chlorothalonil fungicide compared with Fusarium culmorum the causal fungus of head blight disease of wheat.(ii)Acquisition of Trichoderma isolates high resistance potential toward effective concentrations of chlorothalonil without affecting their bio-control potential.

\section{MATERIALS AND METHODS}

\section{Trichoderma isolates}

Trichoderma isolates showing typical morphological and microscopic characterization corresponding to Trichoderma genus were isolated from rhizosphere of different host plants grown in many fields cultivated with many crops. Identification of Trichoderma isolates up to species level was carried out at department of plant pathology, Faculty of Agriculture; 
Menoufia University based on Gams and Bissett (2002) Key. Single spore technique was used to obtain pure cultures of identified Trichoderma isolates. Pure cultures were railed on Potato Dextrose Agar media (PDA) amended with $150 \mathrm{mg}$ of chloramphenicol antibiotic and stored at $-20^{\circ} \mathrm{C}$ for further investigations.

Exposure of isolates to ionizing radiation to obtain new genotypes.

The obtained Trichoderma isolates were exposed to different doses of gamma radiation by irradiated 7 days old culture with doses of $0.0,0.02 ; 0.05 ; 0.1 ; 0.25 ; 0.5 ; 1.0 ; 2.0$ and 5.0 KGy. Radiation treatments were carried out with J 6600-Cobalt-60 Irradiator, Atomic Energy Authority, Cairo, Egypt.

Table (1) key of 11 tested Trichoderma isolates adapted to gain resistance against chlorothalonil fungicide.

\begin{tabular}{|c|c|l|}
\hline Serial & Code & \multicolumn{1}{|c|}{ Name } \\
\hline 1 & T1 & Trichoderma veridi, wild type \\
\hline 2 & T1G1 & T. veridi Mutation 1 \\
\hline 3 & T2 & Trichoderma harzianum wild type, \\
\hline 4 & T2G1 & T. harzianum mutation1 \\
\hline 5 & T2G2 & T. harzianum mutation2 \\
\hline 6 & T3 & Trichoderma longibrachiatum, wild type \\
\hline 7 & T3G1 & T. longibrachiatum mutation 1 \\
\hline 8 & T3G2 & T. longibrachiatum mutation 2 \\
\hline 9 & T4 & Trichoderma koningii, wild type \\
\hline 10 & T4G1 & T. koningii mutation 1 \\
\hline 11 & T4G2 & T. koningii mutation 2 \\
\hline
\end{tabular}

\section{Source and inoculum of the causal organism}

All in vitro and in vivo tests were conducted using standard tester isolates of $F$. culmorum which was provided by CIMMYT (International Maize and Wheat Improvement Centre), Turkey. This isolate showed the most aggressiveness and severed infection symptoms on different wheat cultivars. Pure sub-cultures of pathogenic $F$. culmorum isolate were maintained on PDA amended with Chloramphenicol and stored in -20 deep freezer for next investigations. For the upcoming experiments, used fungi re-cultured continuously on PDA plates to provide a fresh mycelium. the coming experiments used fungi re-cultured continuously on PDA plates to provide a fresh mycelium.

\section{Fungicide and Chemicals Used}

Bravo fungicide (70\% Chlorothalonil) was purchased from Syngenta, Turkey. while all other chemicals i.e., PDA, agar and antibiotics were purchased from Sigma-Aldrich.

\section{In-Vitro Bio-Control Activity}

Bio-control potential of the tested Trichoderma isolates against $F$. culmorum was determined using dual culture technique. One $\mathrm{cm}$ in diameter fresh mycelium of each individual Trichoderma isolate was placed at one side $(1 \mathrm{~cm}$ from the edge) of $9 \mathrm{~cm}$ Petri dishes containing 50\% PDA medium. Similar disk in size (1 cm in diameter) of $F$. culmorum isolate was placed on the opposite side of the inoculated Petri dishes. Control plates were inoculated only with equal disks of only $F$. culmorum isolate without Trichoderma disks. Three replicates were made for each treatment. All plates were incubated at $24-25^{\circ} \mathrm{C}$. Experiment was terminated when $F$. culmorum mycelial growth covered control plates. 
Radial growth of both Trichoderma and Fusarium isolates, inhibition zone, sporulation potential and overgrowth type of Trichoderma isolates were recorded.

\section{Microscopic examination of interaction between Fusarium culmorum and Trichoderma} isolates

Half $\mathrm{cm}$ in diameter disk of each individual Trichoderma isolate reread on PDA media was placed at one side on glass slide placed in $9 \mathrm{~cm}$ petri dish containing $1.5 \%$ agarose gel. Similar disk in size $(0.5 \mathrm{~cm}$ in diameter) taken from $F$. culmorum pure culture was placed on the opposite side of the glass slide. All plates were incubated at 24-25C till intermingling between Fusarium and Trichoderma isolates. Glass slide was cut through and removed from Petri dishes before investigated using light microscope at magnification power 400x.

\section{Sensitivity to chlorothalonil Fungicide}

Sensitivity of both Trichoderma isolates and $F$. culmorum isolates toward Chlorothalonil fungicide was evaluated under in-vitro conditions. Chlorothalonil stock solution was prepared with concentration of $1 \mathrm{mM}(266 \mathrm{mg} / \mathrm{L}=147.78 \mu \mathrm{L} / \mathrm{L})$ and stored in the dark till using. For obtaining the desired concentrations i.e. 0.1, 0.2, 0.4, 0.8 and $1.2 \mu \mathrm{M}$ from chlorothalonil immediately prior the test.

One disk $(1 \mathrm{~cm})$ from each Trichoderma isolates as well as from $F$. culmorum isolate was transferred individually into centers of Petri dishes $(9 \mathrm{~cm}$, in diameter) containing $50 \%$ PDA media treated with EC50 dose $(1.2 \mu \mathrm{M})$ of chlorothalonil. Three replicates were made for each isolate. Petri dishes containing only 50\% of PDA media without fungicide were used as control. All dishes were incubated in growth chambers lighted for 12 hours/day with double florescent and violet lambs. Experiment was terminated when fungal growth was completed with any of the control plates. Radial growth of each isolate either with treated or un-treated plates with fungicide was recorded and growth reduction was calculated based on the following equation:

Percentage of Growth Reduction $=\frac{C-T}{C} \times 100$

While $\mathrm{C}=$ Average of radial growth within control plates and $\mathrm{T}=$ Average of radial growth within fungicide treated plates.

\section{Acquisition of Trichoderma isolates resistance toward chlorothalonil}

To increase the tolerance potential of selected Trichoderma isolates toward chlorothalonil gradient concentrations $(0.1,0.2,0.4,0.8$ and $1.2 \mu \mathrm{M})$ technique was used. Individual disks $(1 \mathrm{~cm}$ in diameter) from Trichoderma isolates treated originally with $1.2 \mu \mathrm{M}$ of chlorothalonil (EC50 dose) were sub-cultured first on PDA medium amended with $0.1 \mu \mathrm{M}$ of chlorothalonil and incubated at $25{ }^{\circ} \mathrm{C}$. After each 72 hours, new disks were taken from cultures treated with the lower concentration and transferred into plates treated with next higher concentration up to the higher used concentration. For example, isolates grown on cultures treated with $0.1 \mu \mathrm{M}$ and incubated at $25{ }^{\circ} \mathrm{C}$ for 72 hours then mycelium disc transferred into plates treated with $0.2 \mu \mathrm{M}$ of fungicide and incubated at $25^{\circ} \mathrm{C}$. After 72 hours individual disks were transferred into dishes treated with $0.4 \mu \mathrm{M}$ etc.

\section{Evaluation of Acquisition of Trichoderma isolates resistance toward chlorothalonil}

To confirm the potency of acquisition resistance toward chlorothalonil, In-Vitro experiment was conducted to determine the radial growth of four different Trichoderma wild isolates (T1. T2. T3 and T4) and seven different modified Trichoderma genotypes (T1.G1, 
T2.G1, T2.G2, T3.G1, T3.G2, T4.G1 and T4.G2) and recorded with one F. culmorum isolate (Fus.) in PDA amended with $(0.8 \mu \mathrm{M})$ chlorothalonil compared with the same isolates but cultured on non-amended PDA plates.

\section{RESULTS}

\section{Bio-Control Efficiency:}

Antagonistic potential of four different Trichoderma isolates belonging to four Trichoderma species i.e., Trichoderma viride, T. harzianum, T. longibrachiatum and $T$. koningii (T1, T2, T3 and T4) in addition to Seven modified genotypes i.e., T1.G1, T2.G1, T2.G2, T3.G1, T3.G2, T4.G1 and T4.G2 was determined under in vitro condition against $F$. culmorum the causal pathogen of wheat crown rot (fig.1). The results showed that all tested Trichoderma isolates positively affected and inhibited the mycelium growth of pathogenic Fusarium under test conditions in comparison with $F$. culmorum alone. The highest reduction percentage of $F$. culmorum was recorded with T2.G1 and T3.G2 isolates by $75 \%$ followed by T2.G2, T3.G1 isolates by 70\% while the least reduction percentage was recorded with T2, T3 and T4 isolate by $60 \%$ as presented in fig (2).

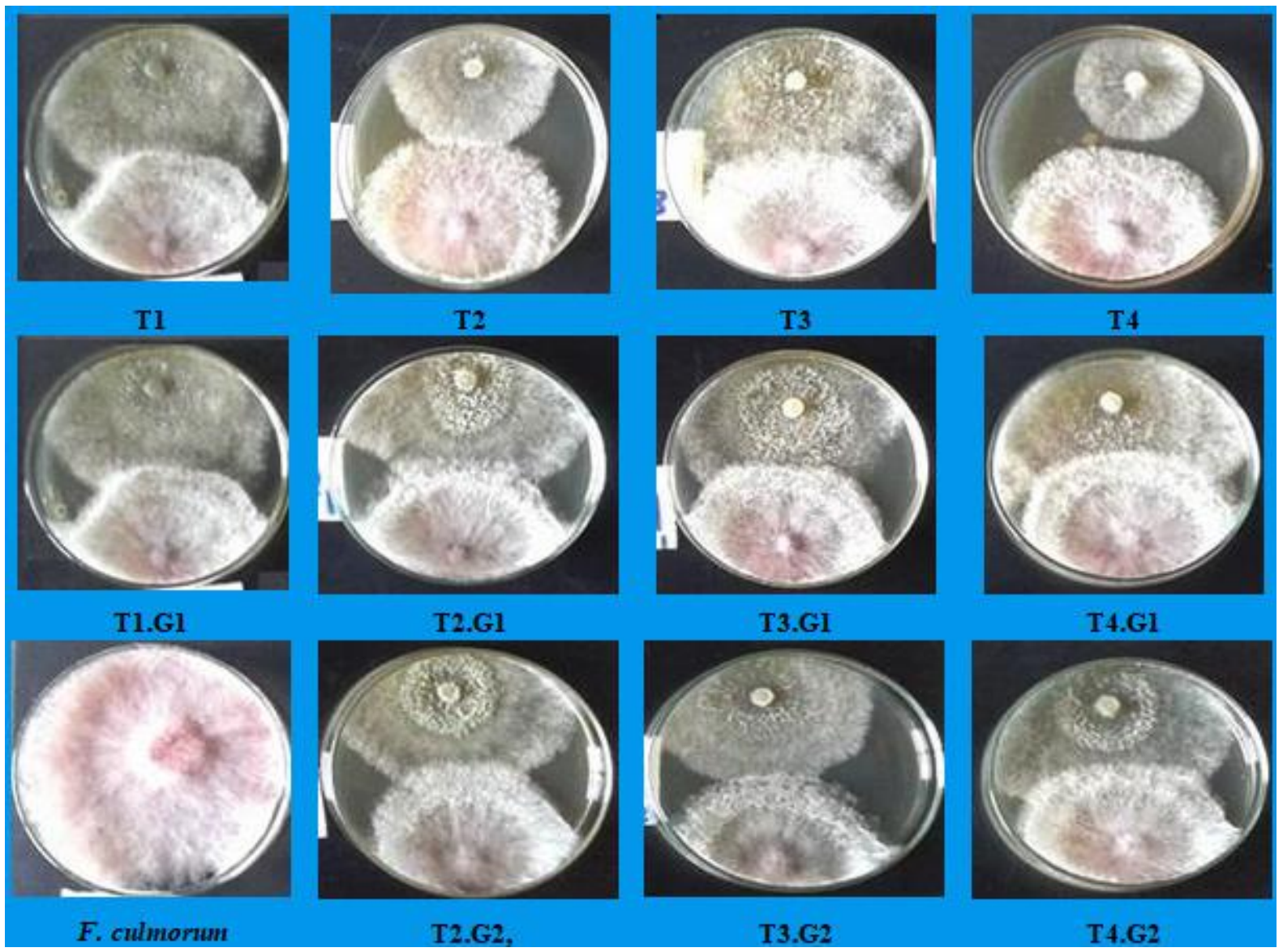

Figure 1. Dual culture test conducted with four different Trichoderma wild isolates (T1. T2. T3 and T4) and six different modified Trichoderma genotypes (T2.G1, T2.G2, T3.G1, T3.G2, T4.G1 and T4.G2). 


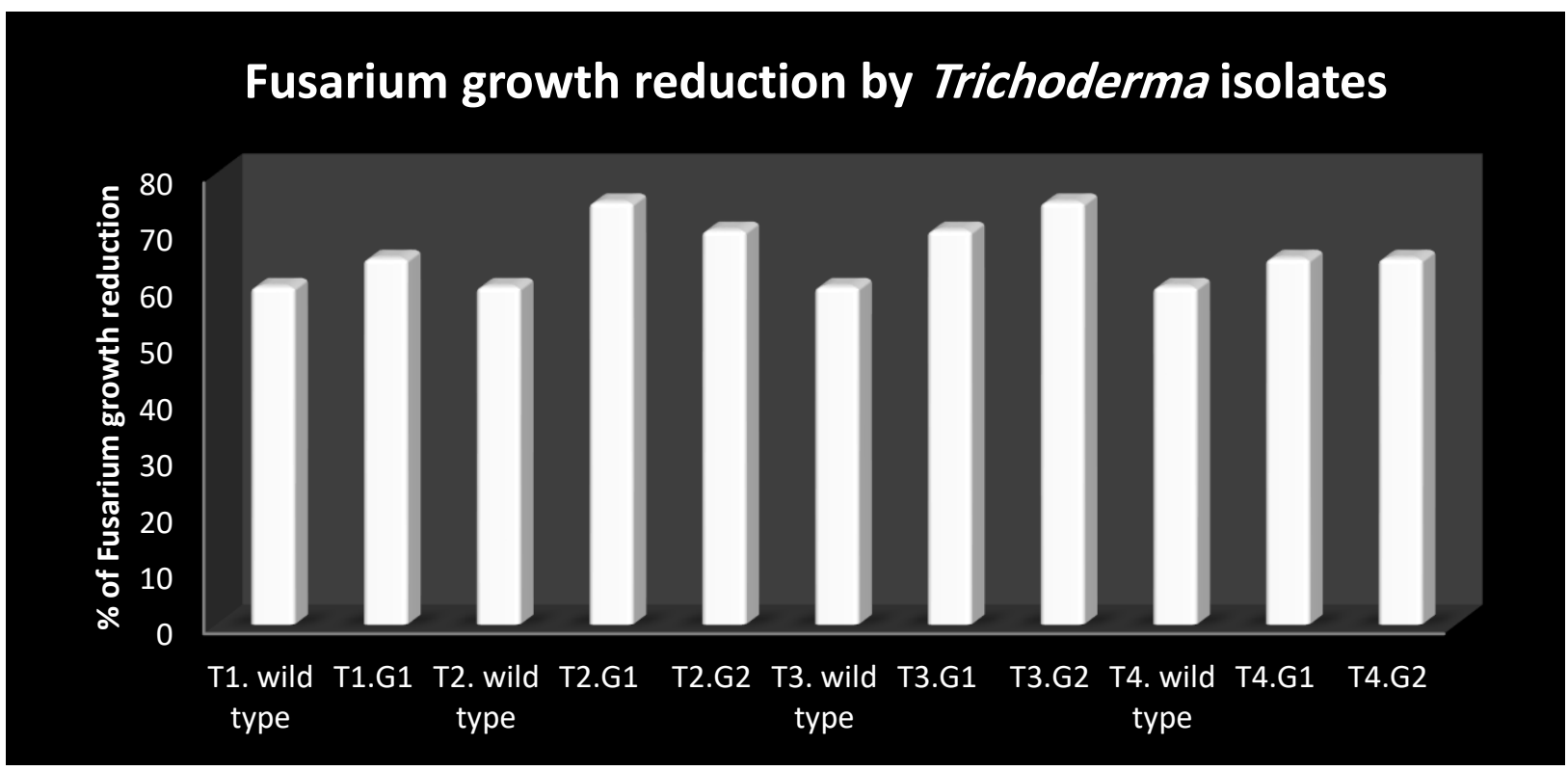

Figure 2. Reduction percentage of F. culmorum conducted with four different Trichoderma wild isolates (T1. T2.P T3 and T4) and six different modified Trichoderma genotypes (T2.G1, T2.G2, T3.G1, T3.G2, T4.G1 and T4.G2) under in vitro conditions.

\section{Microscope examination of interaction between $F$. culmorum and Trichoderma}

Microscope examination was done using light microscope at the intermingling zone between $F$. culmorum and Trichoderma isolates to infer size the mode of action and possible interactions between the two interacting fungi. The captured micrographs showed that Trichoderma hyphae are attached longitudinally to $F$. culmorum hyphae and forming hyphal coiling then hyphal penetration. Our results revealed that the Trichoderma tolerant chlorothalonil is a good mycoparasitic organism as we investigated the hyperparasitism of $T$. harzianum by forming appressoria over the pathogenic hyphae of $F$. culmorum by tightly coiling around it within 48 hours. We have to mention that the pathogenic fungus was inhibited completely, while the biocontrol agent i. e. Trichoderma was multiplied efficiently by conidiogenesis. We noticed mycoparasitic activities as well as antibiosis against the pathogenic fungus. In Fig.3, the microscopic observations on hyphal interaction showed obviously that biocontrol agent or the antagonist Trichoderma, sometimes grew parallel to the pathogen hyphae, then coiled around and penetrated the hyphae of the Fusarium by producing a hook or a knob-like structure (appressorium) as shown in microscopic figures.

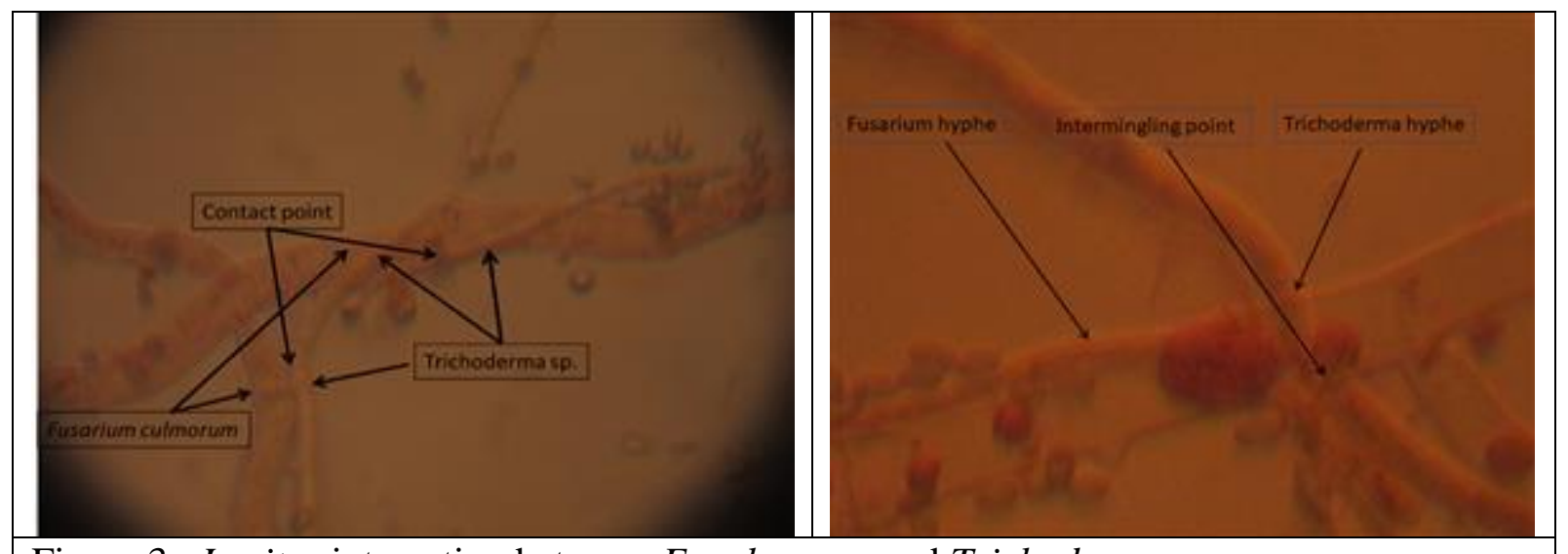

Figure 3. In vitro interaction between $F$. culmorum and Trichoderma 


\section{Resistance potential against chlorothalonil fungicide}

Sensitivity of 11 different Trichoderma isolates in addition to pathogenic F. culmorum toward chlorothalonil fungicide was determined using Ec50 dose. The obtained results revealed that all tested fungal isolates were sensitive and no tolerance potential against chlorothalonil was detected. The mycelial growth reduction was ranged from $28.95 \%$ $63.75 \%$ with the tested Trichoderma isolates while it reached up to $32.87 \%$ with $F$. culmorum isolate (fig.4).

\section{Acquisition of Trichoderma isolates resistance toward chlorothalonil}

To stimulate the tolerance potential of Trichoderma isolates toward chlorothalonil, the isolates were grown on plats treated with Ec50 dose and consequently sub-cultured on serial ascending concentrations of the fungicide i.e., $0.1,0,2,0,4$ and $0,8 \mu \mathrm{M}$. The recorded results with isolates transferred from Ec50 dose to concentration of $0.1 \mu \mathrm{M}$, illustrated that the inhibitory effect of fungicide on growth of both Trichoderma and Fusarium isolates was still detectable (table 2). The highest mycelial reduction $(33,77 \%)$ was recorded with isolate T2.G2 followed by isolate T4.G2.(30\%) while the lowest reduction $(6,77 \%)$ was observed with isolate T2.G1. The inhibition percentage was reached up to $29,37 \%$ with pathogenic $F$. culmorum isolate (fig.5).

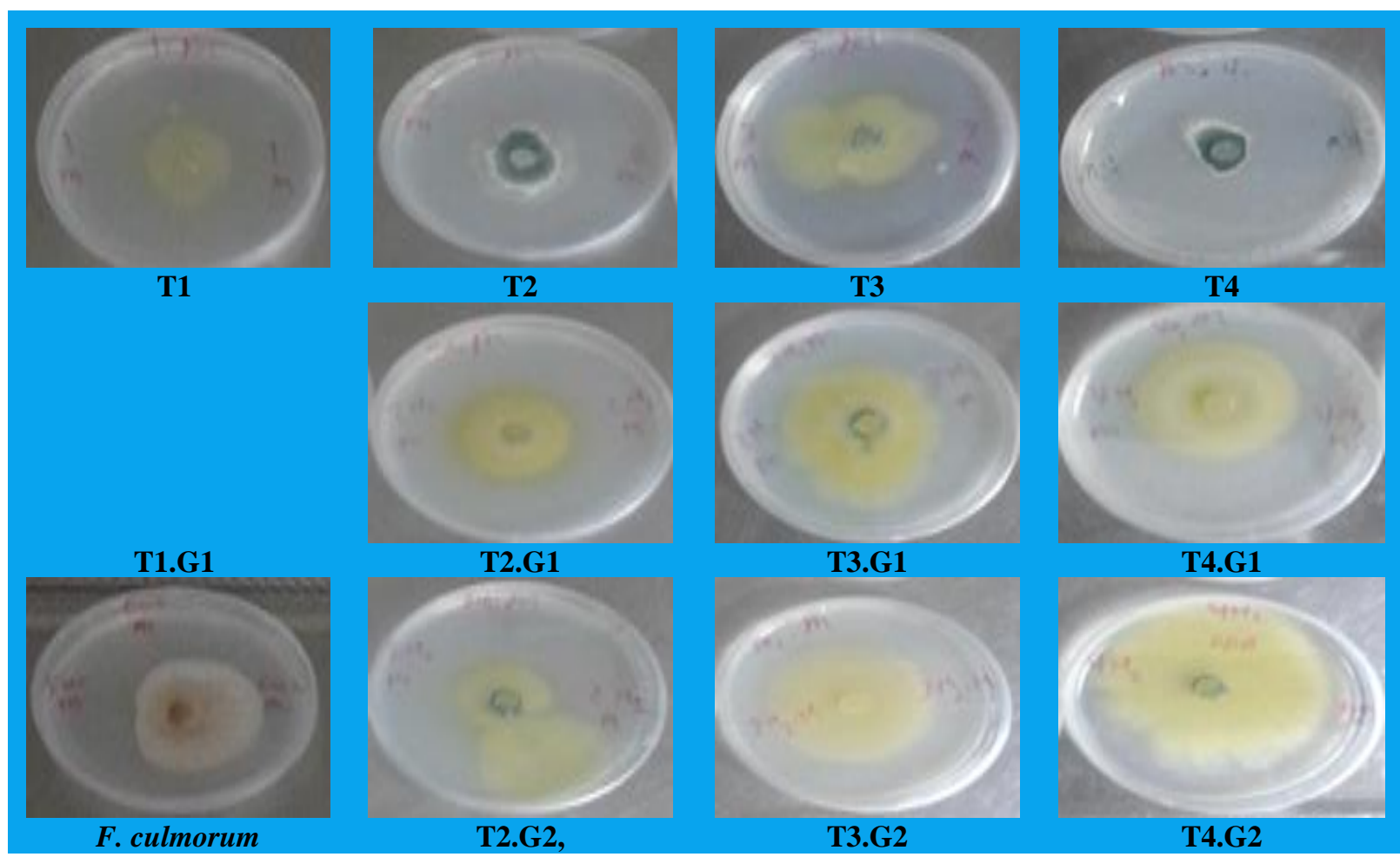

Figure 4. Radial growth recorded with one F. culmorum isolate (Fus.), four different Trichoderma wild isolates

(T1. T2. T3 and T4) and six different modified Trichoderma genotypes (T2.G1, T2.G2, T3.G1, T3.G2,

T4.G1 and T4.G2) cultured on PDA dishes treated with (1.2 $\mu \mathrm{M}=$ EC50) chlorothalonil.

Similar results were recorded with isolates transferred from plants treated with $0.1 \mu \mathrm{M}$ to plats amended with $0.2 \mu \mathrm{M}$ of chlorothalonil. However, the results showed that T3. G2 and T4.G1 were considered the most tolerant isolates among all tested Trichoderma isolates. Thus, the inhibitory effect of fungicide was recorded $0,27 \%$ and $0,96 \%$, respectively (fig.6, fig.7, fig.8, fig.9 and fig.10). The final results revealed that the tolerance potential of all Trichoderma isolates tested toward chlorothalonil was increased thus the negative influence of fungicide on Trichoderma isolates growth parameters was decreased significantly as a result of the adaptation technique used in present study (fig.11). Moreover, the results 
demonstrated that the obtained genotypes using radiation technique was superior in resistance potential against chlorothalonil compering to wild types (fig.11). remarkably, the reduction percentages of Trichoderma radial growth were dropped from more than 55\% pre-adaptation to zero \% after adaptation procedure as recorded with most of Trichoderma generated genotypes (fig.11).

Table (2): Inhibition percentage of 11 different Trichoderma strains cultured on PDA media amended with gradual concentrations $(0.1,0.2,0.4,0.8,1,1.2 \mu \mathrm{M})$ of chlorothalonil.

\begin{tabular}{|c|c|c|c|c|c|c|c|}
\hline \multirow{2}{*}{$\begin{array}{c}\text { Nerial } \\
\text { No. }\end{array}$} & \multicolumn{7}{|c|}{ Inhibition (\%) } \\
\cline { 2 - 8 } & $\mathbf{c o d e}$ & $\mathbf{0 . 1} \boldsymbol{\mu M}$ & $\mathbf{0 . 2} \boldsymbol{\mu M}$ & $\mathbf{0 . 4} \boldsymbol{\mu M}$ & $\mathbf{0 . 8} \boldsymbol{\mu M}$ & $\mathbf{1} \boldsymbol{\mu M}$ & $\mathbf{1 . 2} \boldsymbol{\mu M}=\mathbf{M c 5 0}$ \\
\hline $\mathbf{1}$ & $\mathrm{T} 1$ & 26.27 & 21.51 & 4.48 & 0.00 & 42.37 & 0.00 \\
\hline $\mathbf{2}$ & $1 \mathrm{M} 1$ & 20.24 & 25.00 & 26.00 & 26.00 & 35.71 & 26.00 \\
\hline $\mathbf{3}$ & $\mathrm{T} 2$ & 23.39 & 39.76 & 5.61 & 2.94 & 54.39 & 13.89 \\
\hline $\mathbf{4}$ & $2 \mathrm{M} 1$ & 6.77 & 5.88 & 3.02 & 6.67 & 34.59 & 0.00 \\
\hline $\mathbf{5}$ & $2 \mathrm{M} 2$ & 33.77 & 5.71 & 3.98 & 8.63 & 50.99 & 0.00 \\
\hline $\mathbf{6}$ & $\mathrm{T} 3$ & 17.68 & 6.49 & -0.22 & 0.00 & 56.71 & 0.00 \\
\hline $\mathbf{7}$ & $3 \mathrm{M} 1$ & 29.88 & 22.50 & 0.00 & 0.00 & 48.17 & 0.00 \\
\hline $\mathbf{8}$ & $3 \mathrm{M} 2$ & 9.21 & -0.27 & 2.46 & 0.00 & 28.95 & 0.00 \\
\hline $\mathbf{9}$ & 4 & 16.25 & 68.10 & 7.14 & 5.88 & 63.75 & 23.11 \\
\hline $\mathbf{1 0}$ & $4 \mathrm{M} 1$ & 20.47 & -0.96 & 3.54 & 0.00 & 47.37 & 0.00 \\
\hline $\mathbf{1 1}$ & $4 \mathrm{M} 2$ & 30.00 & -2.50 & -23.84 & 1.96 & 24.00 & 0.00 \\
\hline $\mathbf{1 2}$ & Fusarium & 29.37 & $\ldots \ldots \ldots$ & $\ldots \ldots \ldots$ & 7.95 & 32.87 & 48.89 \\
\hline
\end{tabular}

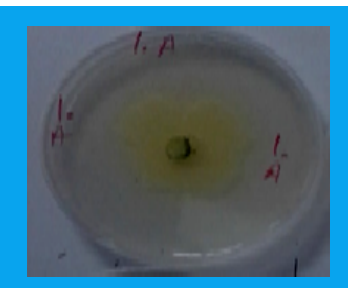

T1

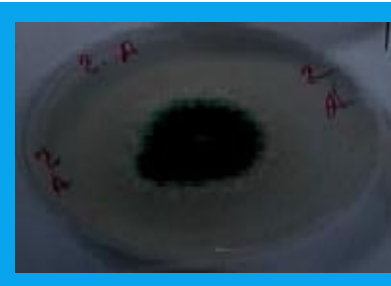

T2

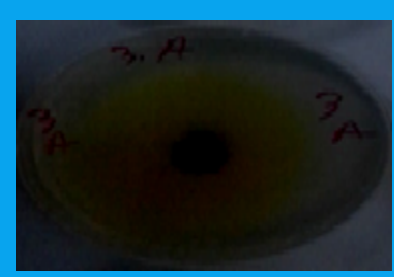

T3

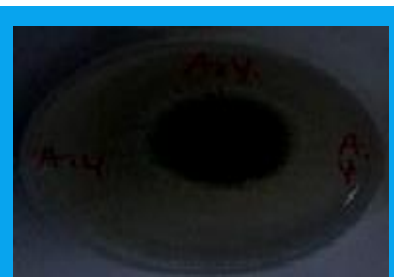

T4

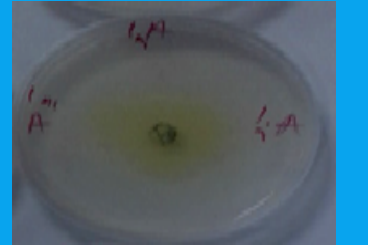

T1.G1

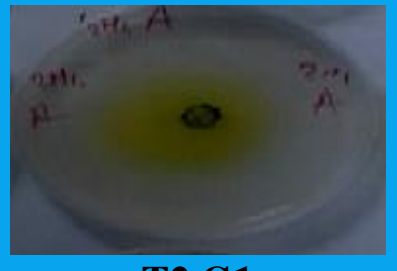

T2.G1

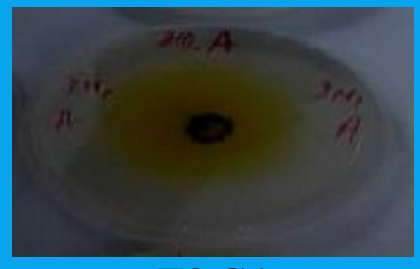

T3.G1

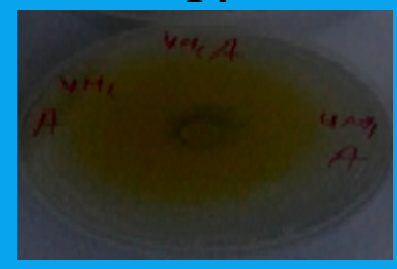

T4.G1

\section{F. culmorum}

T2.G2,

T3.G2

T4.G2

Figure 5. Radial growth recorded with one F. culmorum isolate (Fus.), four different Trichoderma wild isolates (T1. T2. T3 and T4) and seven different modified Trichoderma genotypes (T1.G1, T2.G1, T2.G2,

T3.G1, T3.G2, T4.G1 and T4.G2) cultured on PDA dishes treated with $(0.1 \mu \mathrm{M})$ chlorothalonil. 


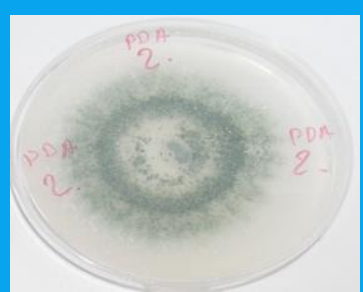

T1

$\mathbf{T} 2$

T3

T4
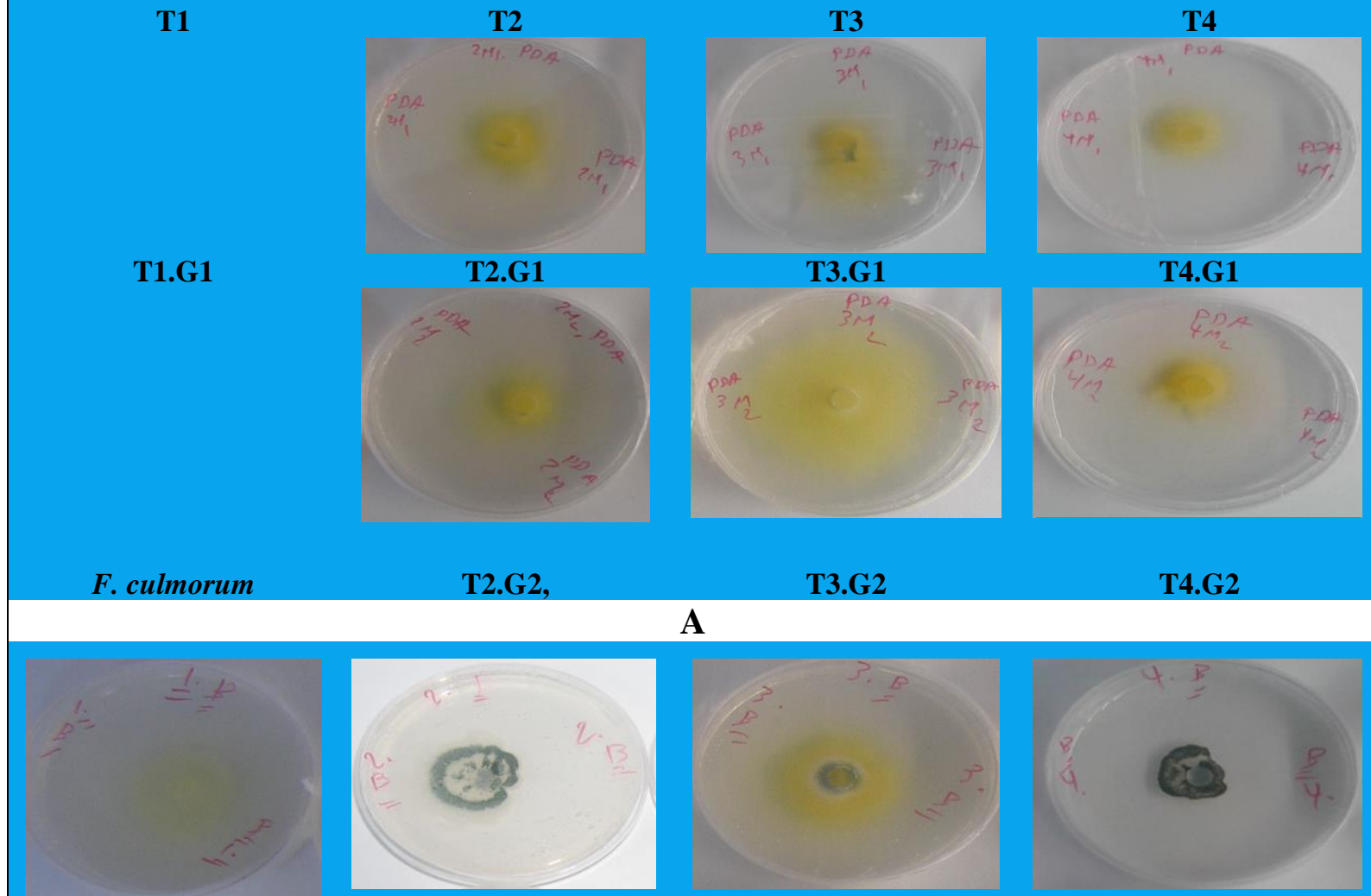

T4.G1
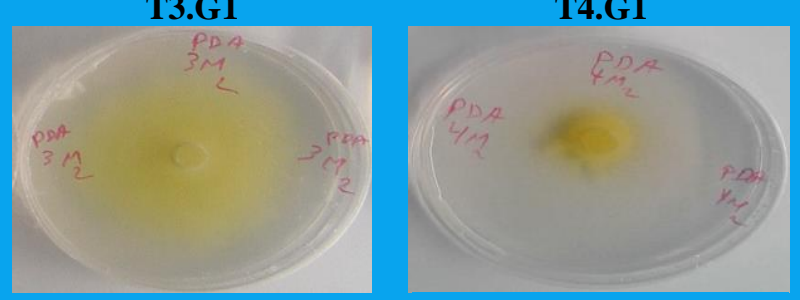

T4.G2

\section{A \\ A}

T3.G2

T1

T2
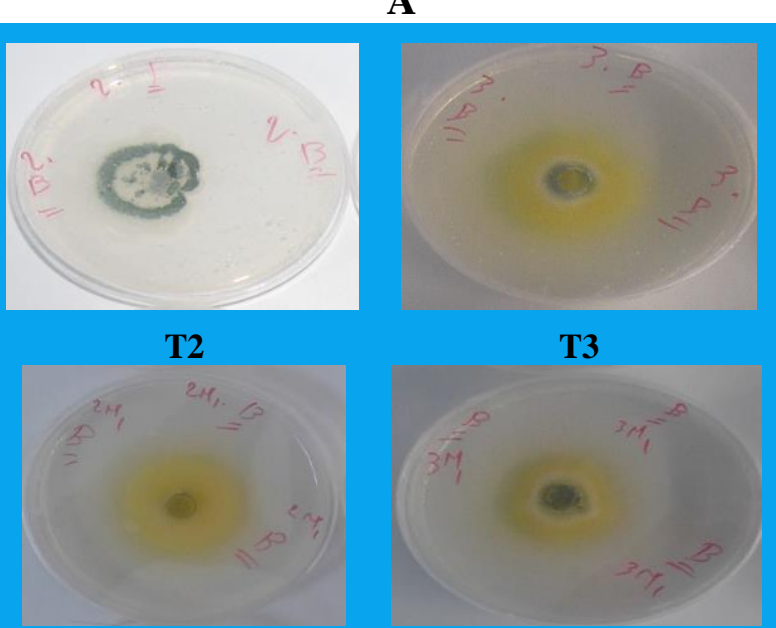

T1.G1

T2.G1

T2.G2

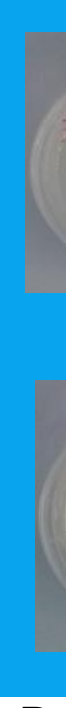

T3

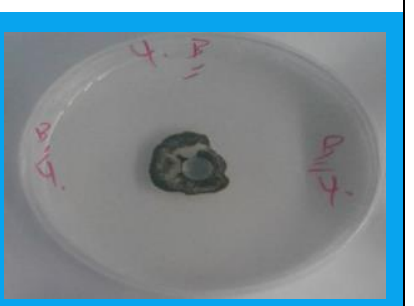

T4

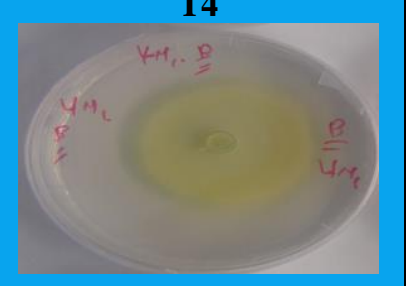

T3.G1

T4.G1

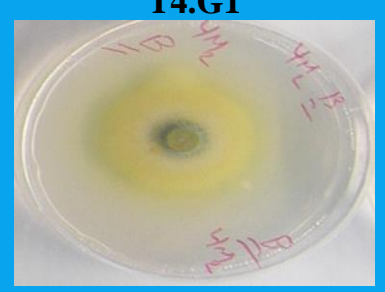

T3.G2

T4.G2

B

Figure 6. Radial growth recorded with one F. culmorum isolate (Fus.), four different Trichoderma wild isolates (T1. T2. T3 and T4) and six different modified Trichoderma genotypes (T1.G1, T2.G1, T2.G2, T3.G1, T3.G2, T4.G1 and T4.G2) originally cultured on PDA dishes and transferred to PDA plates (A) and to PDA amended with $(0.2 \mu \mathrm{M})$ chlorothalonil $(\mathrm{B})$. 


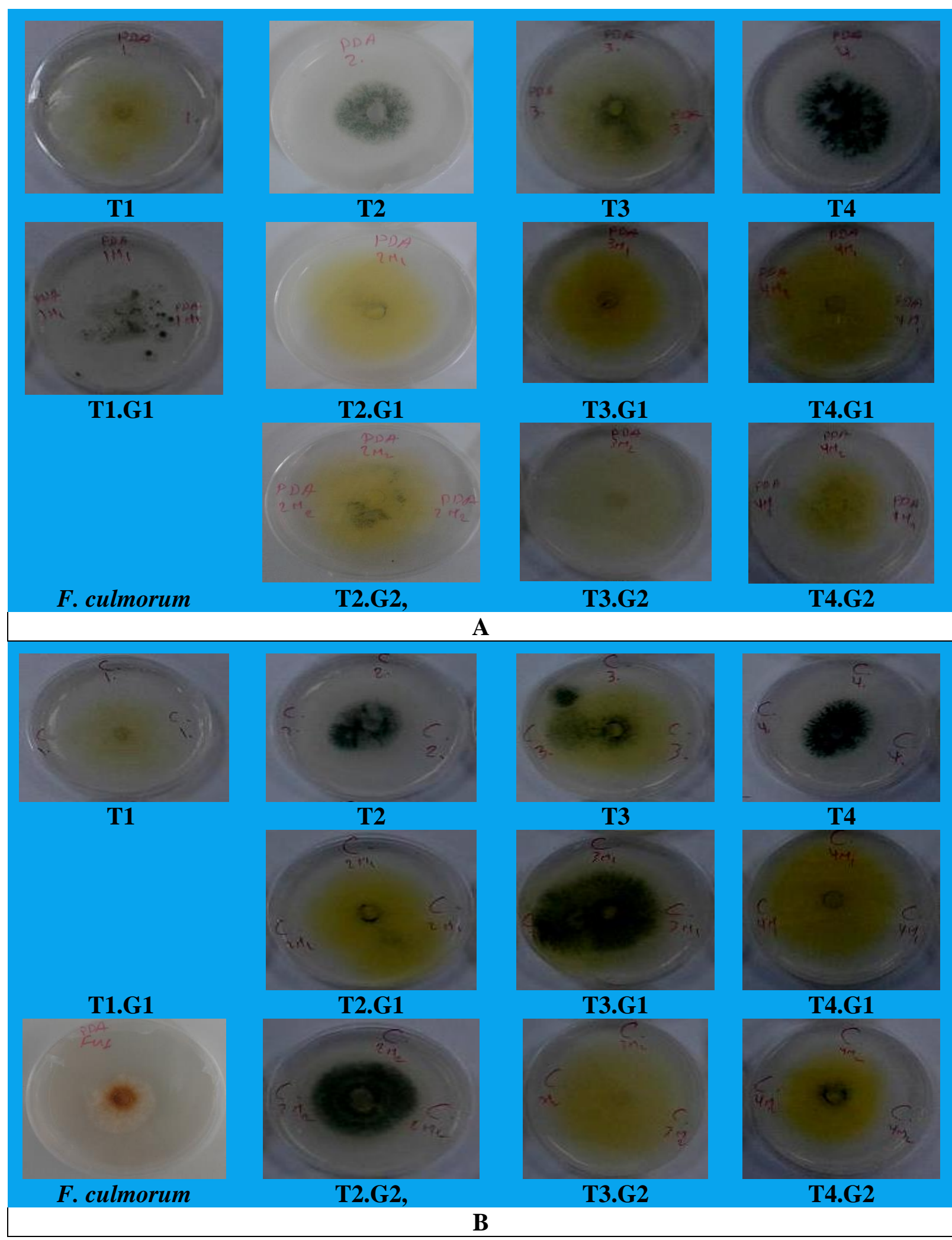

Figure 7. Radial growth recorded with one $F$. culmorum isolate (Fus.), four different Trichoderma wild isolates (T1. T2. T3 and T4) and six different modified Trichoderma genotypes (T1.G1, T2.G1, T2.G2, T3.G1, T3.G2, T4.G1 and T4.G2) originally cultured on PDA dishes and transferred to PDA plates (A) and to PDA amended with $(0.4 \mu \mathrm{M})$ chlorothalonil (B). 


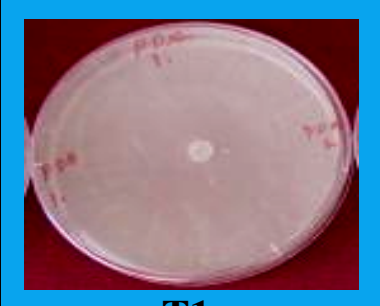

T1

T1.G1

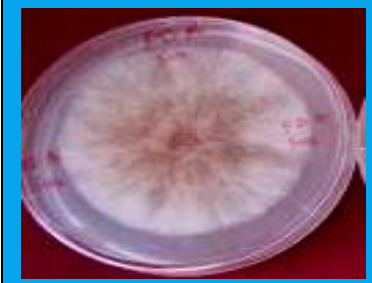

F. culmorum

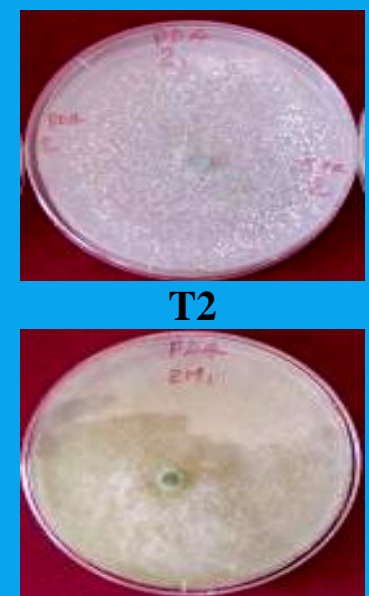

T2.G1

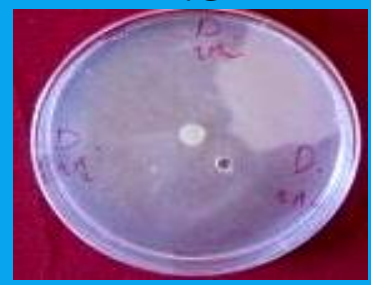

T2.G2,

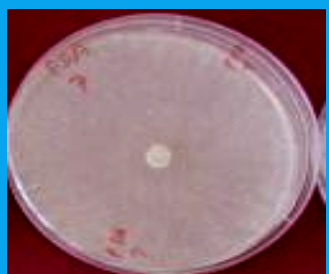

T3

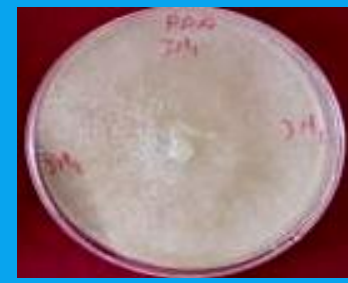

T3.G1

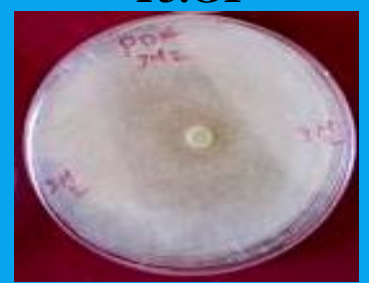

T3.G2

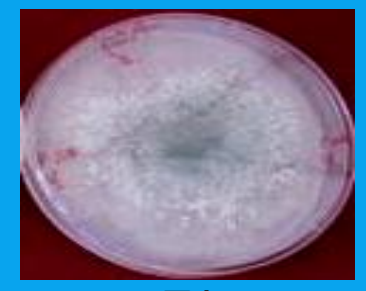

T4

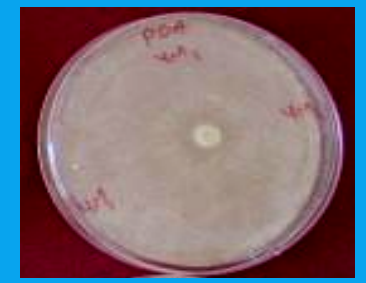

T4.G1

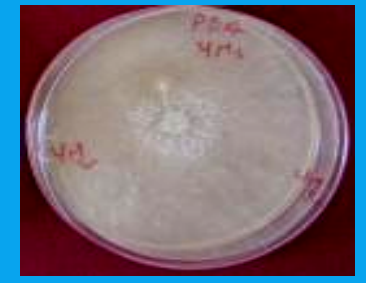

T4.G2

A

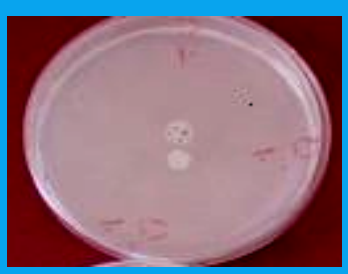

T1

T1.G1

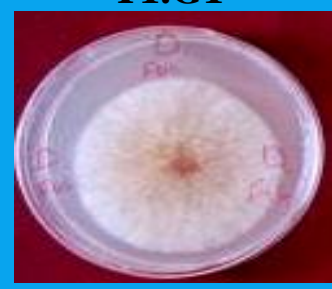

F. culmorum

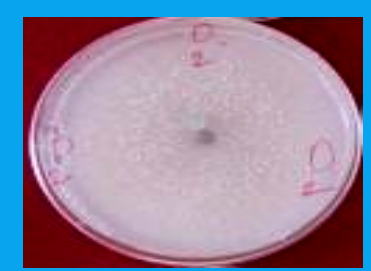

T2

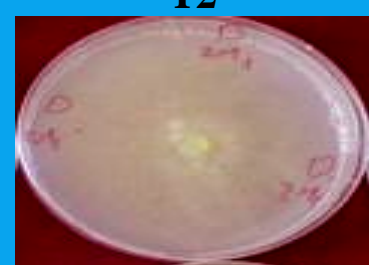

T2.G1

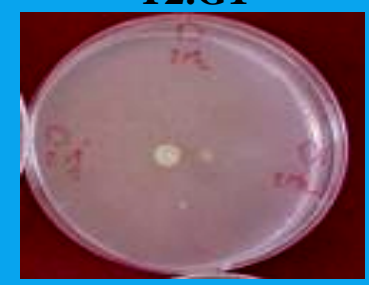

T2.G2,

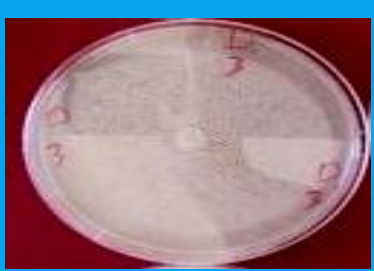

T3

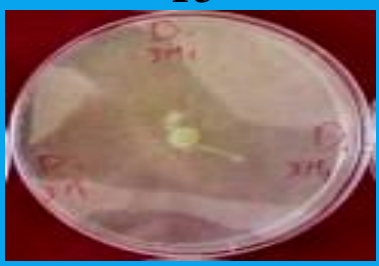

T3.G1

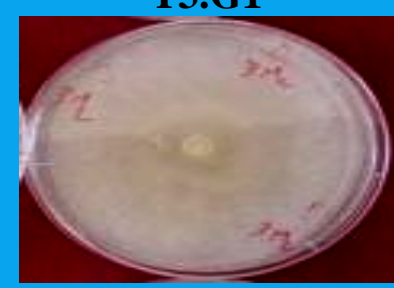

T3.G2

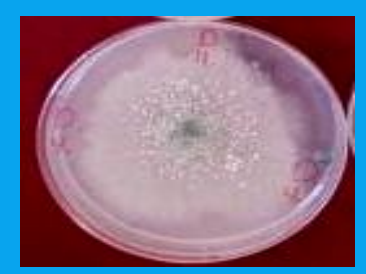

T4

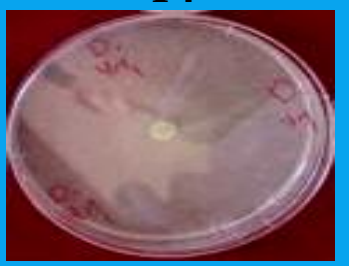

T4.G1

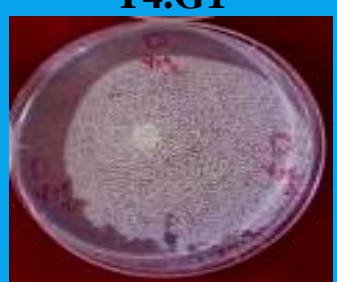

T4.G2

B

Figure 8. Radial growth recorded with one F. culmorum isolate (Fus.), four different Trichoderma wild isolates (T1. T2. T3 and T4) and six different modified Trichoderma genotypes (T1.G1, T2.G1, T2.G2, T3.G1, T3.G2, T4.G1 and T4.G2) originally cultured on PDA dishes and transferred to PDA plates (A) and to PDA amended with $(0.8 \mu \mathrm{M})$ chlorothalonil (B). 


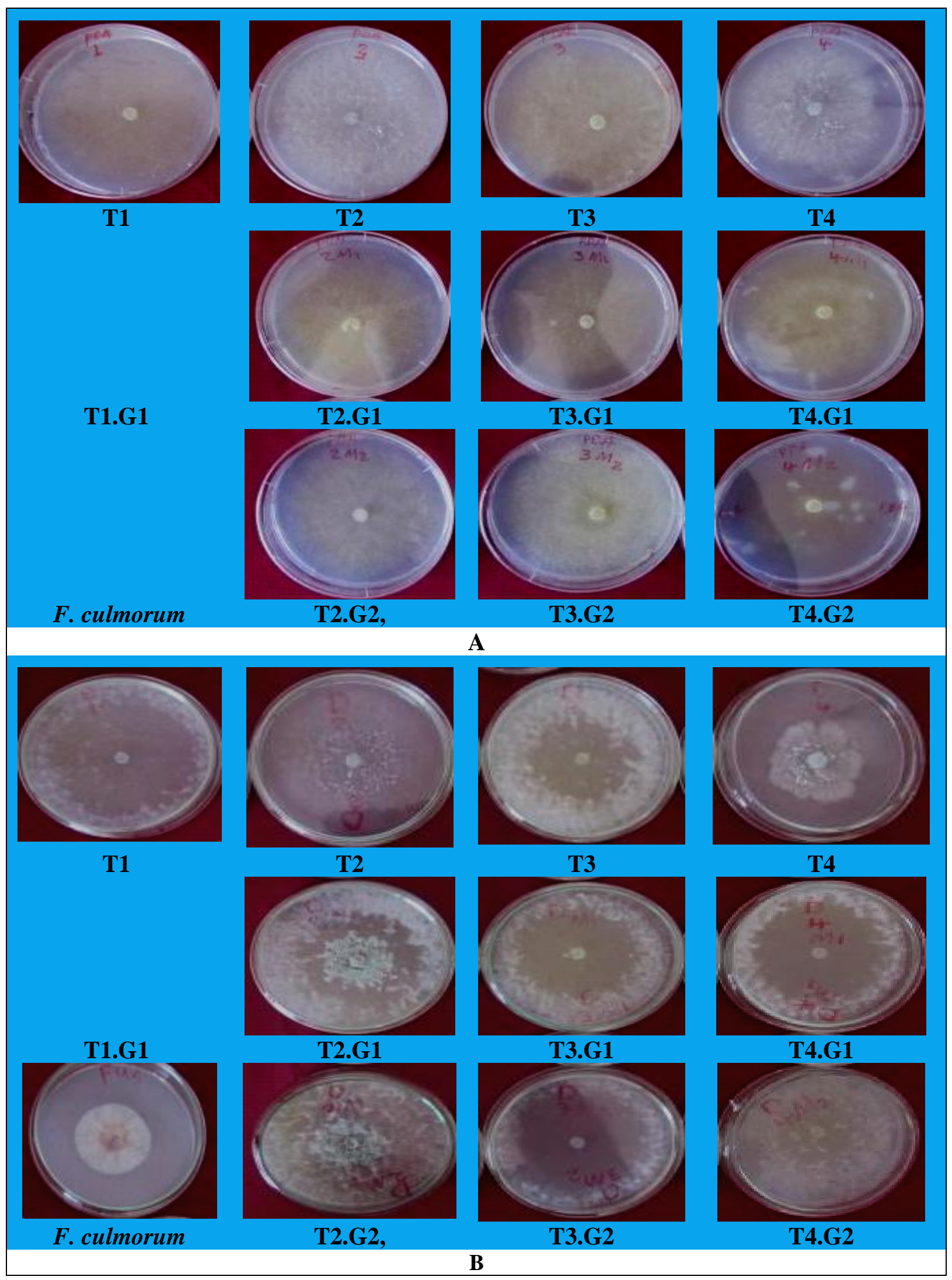

Figure 9. Radial growth recorded with one F. culmorum isolate (Fus.), four different Trichoderma wild isolates (T1. T2. T3 and T4) and six different modified Trichoderma genotypes (T1.G1, T2.G1, T2.G2, T3.G1, T3.G2, T4.G1 and T4.G2) originally cultured on PDA dishes and transferred to PDA plates (A) and to PDA amended with $(1.2 \mu \mathrm{M}=\mathrm{EC} 50)$ chlorothalonil (B). 


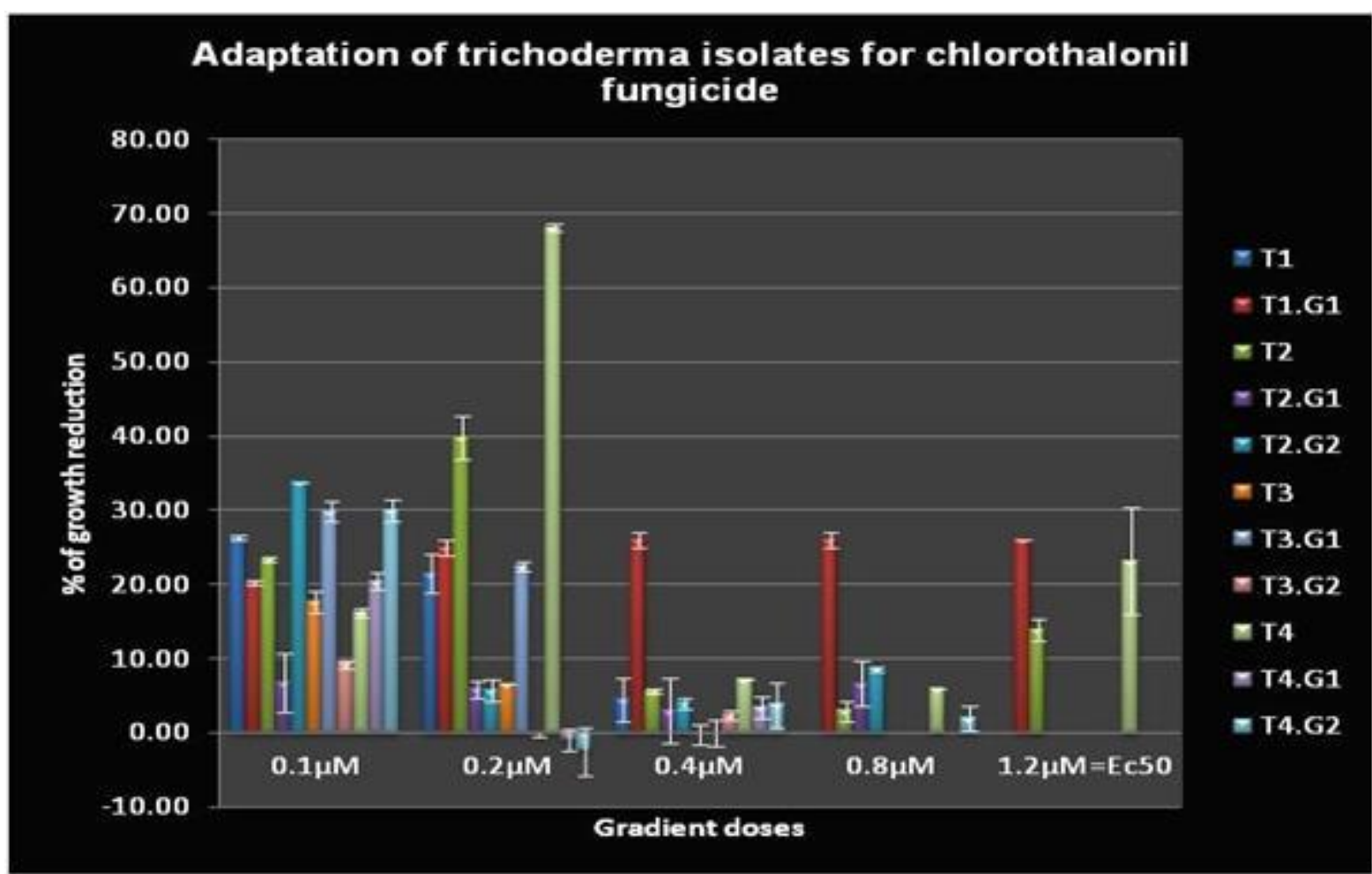

Figure 10. Adaptation of four different Trichoderma wild isolates (T1. T2. T3 and T4) and six different modified Trichoderma genotypes

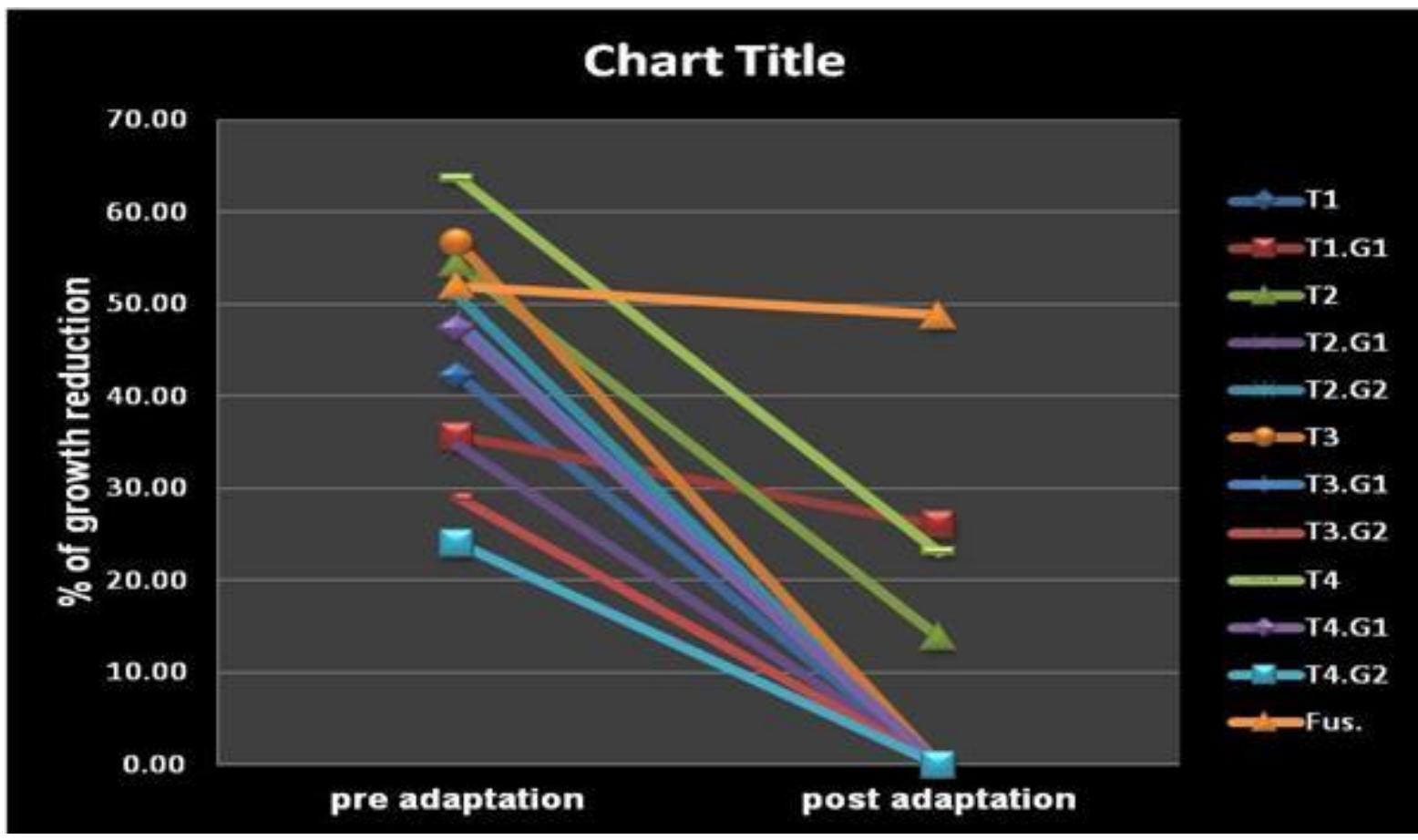

Figure 11. Percentage of radial growth reduction observed by chlorothalonil fungicide with four different Trichoderma wild isolates (T1. T2. T3 and T4) and six different modified Trichoderma genotypes (T1.G1, T2.G1, T2.G2, T3.G1, T3.G2, T4.G1 and T4.G2) before and after adaptation procedure to the fungicide. 
As observed with radial growth of the tested Trichoderma isolates, the obtained results with sporulation performance revealed that the sporulation capability of five different Trichoderma isolates was increased due to the adaptation to chlorothalonil fungicide (fig.12). The highest sporulation was noticed with second genotypes of T. harzianum (T2G2).

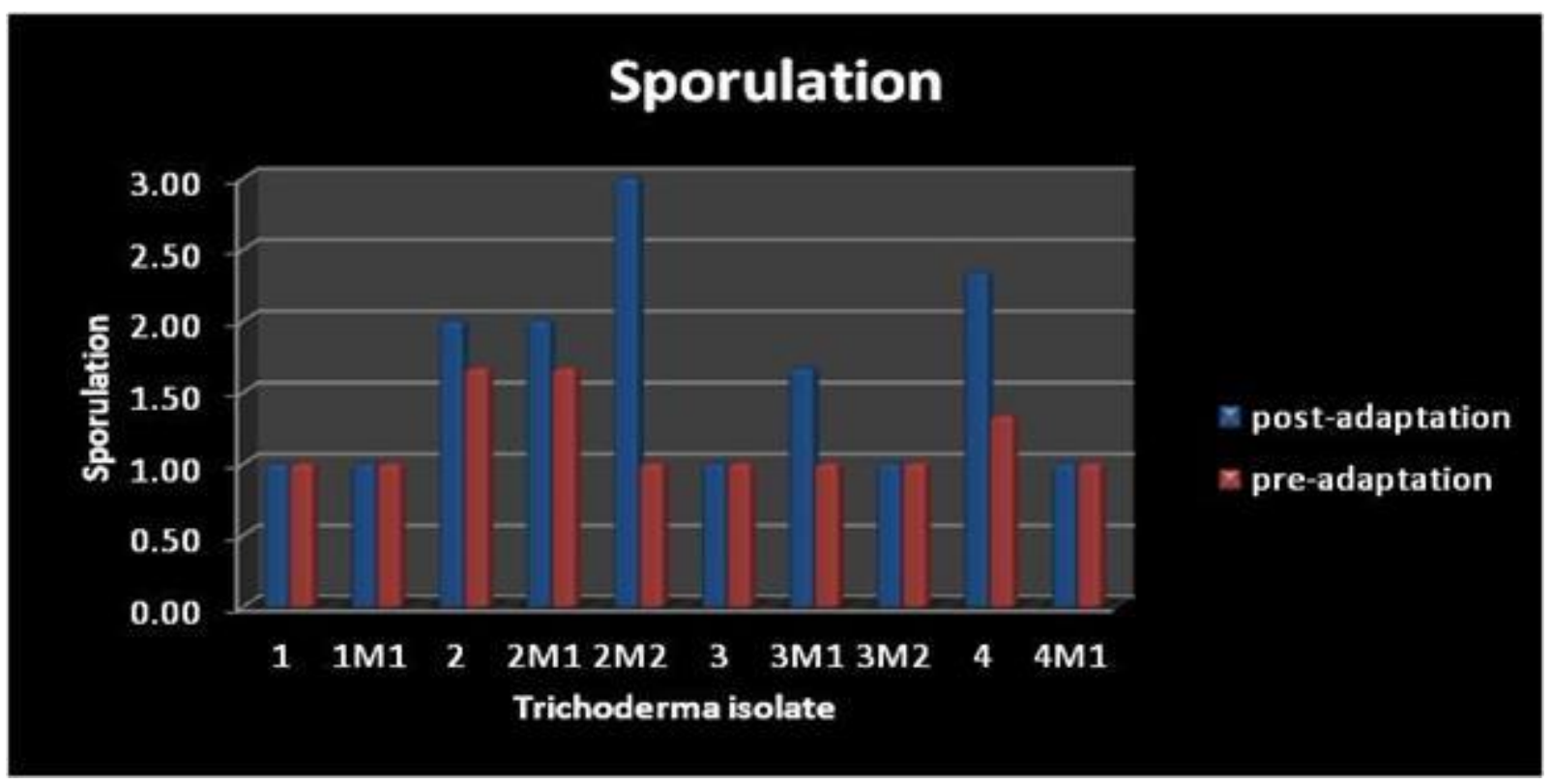

Figure 12. Sporulation potential of four different Trichoderma wild isolates (T1. T2. T3 and T4) and six different modified Trichoderma genotypes before and after adaptation.

\section{DISCUSSION}

Chlorothalonil is one of the broad-spectrum organochlorine fungicides and is the most applied conventional fungicide in the world (Koch $\boldsymbol{e t}$ al., 2013). Furthermore, chlorothalonil is now one of the few fungicides available in the USA to control Asian soybean rust (Deb et al., 2010; Koch et al., 2013). Because it has good adhesion to plants and is in broad use, the residues of chlorothalonil and its metabolites are found in greater quantities in fruits, vegetables, soil and water and can be detected even in the Arctic (Daly et al., 2007). In addition, chlorothalonil may pose a risk to larval amphibians in certain habitats and situations (Yu et al., 2013). As a result, it is listed as a probable human.

Given the fact that Trichoderma can colonize a wide range of many host plants, it must be predictable that Trichoderma have an advanced efficient strategy to change host immunity and to establish a suitable environment for nutrient acquirement and plant reproduction. Unfortunately, many studies showed that Trichoderma fungi were affected negatively with organochlorine pesticides (OCPs) compounds as much as other pathogenic fungi affected. This guide our team to search for a new technology to develop or create a newly tolerant biocontrol agents like Trichoderma that can combat the harsh conditions of polluted soils with OCPs i.e. chlorothalonil and can be antagonistic to soil-borne pathogens.

It is a great worthy to mention that this is the first record worldwide according to our knowledge to produce a new mutant that can work efficiently with chlorothalonil fungicide as an important key for successful integrated pest management. This is an important step during the transfer the old or conventional systems of agriculture to Good Agricultural Practices (Global GAP) and then to Organic Agriculture systems during 2 or 3 years. According to our results, we have to assure that 5 new isolates have a higher sporulation capability compared with the original strains, and this is important to our achieving strategy for building an 
antagonistic soil for controlling soil-borne plant pathogens and hence creating a suppressive soil afterwards. Moreover, most of the new isolates have a great antagonistic opportunity against the causal pathogen i.e. Fusarium culmorum with a higher growth reduction.

Bioproduction of conidia spores is considered an important element in Rhizosphere competence index. All the mutants of each strain and species was determined by the rhizosphere competence assay (Unpublished data, personal communication). Tolerance to chlorothalonil seem to be a necessary element of rhizosphere competence in the soil. Most of the tested mutants were rhizosphere competent in comparison with their wild type parents. Our results revealed that Trichoderma spp. were induced by mutation to increase their linear growth rate and to become rhizosphere competent against many causal pathogens in presence of chlorothalonil which can be one of the most important strategy for controlling soil-borne plant pathogens in soils amended with accumulated pesticides during the last few decades.

\section{CONCLUSION}

Providing a good information about the compatibility of Trichoderma and fungicide applications could encourage the combined application as a part of IPM program for effective plant disease control. Creating an antagonistic soil that was amended with accumulated pesticides by enriched biocontrol agents which have the capabilities for controlling soil-borne fungi like Fusarium culmorum. This is a new trend for creating an antagonistic soil with chlorothalonil tolerant Trichoderma with high efficient condiogenesis and proper growth abilities.

\section{ACKNOWLEDGEMENT}

Authors would like to acknowledge CYMMY, Turkey for providing the pathogen isolate of Fusarium culmorum.

\section{REFERENCES}

Behfar, A., Nazari, Z., Rabiee, M. H., Raeesi, G., Oveisi, M. R., Sadeghi, N., Jannat, B. (2013). The organochlorine pesticides residue levels in Karun river water. Jundishapur Journal of Natural Pharmaceutical Products, 8(1), 41-46. doi:10.5812/jjnpp.6783.

Chaudhuri, M., Zuhali, H., \& Affam, A. C. (2013). Degradation of pesticide chlorothalonil by visible light-responsive photocatalyst ferrioxalate and under solar irradiation. International Journal of Photoenergy. doi: 10.1155/2013/435017.

Chaves, A., Shea, D., \& Danehower, D. (2008). Analysis of chlorothalonil and degradation products in soil and water by GC/MS and LC/MS. Chemosphere, 71(4), 629-638. doi: 10.1016/j.chemosphere.2007.11.015.

Daly, G. L., Lei, Y. D., Teixeira, C., Muir, D. C. G., \& Wania, F. (2007). Pesticides in western Canadian mountain air and soil. Environmental Science \& Technology, 41, 6020-6025. doi:10.1021/es070848o

Deb, D., Engel, B. A., Harbor, J., Hahn, L., Lim, K. J., \& Zhai, T. (2010). Investigating potential water quality impacts of fungicides used to combat soybean rust in Indiana. Water Air and Soil Pollution, 207, 273-288. doi:10.1007/s11270-009-0135-4

Devashree, Y., Dutta, B. K., Paul, S. B., \& Choudhury, S. (2014). The effect of paraquat and fipronil on the soil and rhizosphere microflora of tea (Camellia sinensis (L) O. kuntze). International Journal of Innovation and Applied Studies, 7(4), 1534. 
Eisa, O.A. and El-Feky, N.M. (2014). Impact of the Fungicide Rizolix T50\% on the Antagonistic Activity of Trichoderma harzianum and Trichoderma koningii. Int. J. Sci. Res., 3, 1767-1773.

Gams, W. and J. Bissett (2002). Morphology and identification of Trichoderma. In: Christian P. Kubicek and Gary E. Harman, editors. Trichoderma and gliocladium, Volume 1: basic biology, taxonomy and genetics. London, UK: Taylor and Francis; 1998. p. 3-34.

Gianessi, L. P., \& Marcelli, M. B. (2000). Pesticide use in US crop production: 1997. National Center for Food and Agricultural Policy, Washington, DC.

Hewedy, O.A., Abdel-Lateif, K.S. and Bakr, R.A., 2020. Genetic diversity and biocontrol efficacy of indigenous Trichoderma isolates against Fusarium wilt of pepper. Journal of basic microbiology, 60(2), pp.126-135.

Hu, X.; Roberts, D.P.; Xie, L.; Yu, C.; Li, Y.; Qin, L.; Hu, L.; Zhang, Y.; Liao, X. (2016). Use of formulated Trichoderma sp. Tri-1 in combination with reduced rates of chemical pesticide for control of Sclerotinia sclerotiorium on oilseed rape. Crop Prot., 79, 124127.

Hussen, A., Westbom, R., Megersa, N., Mathiasson, L., \& Björklund, E. (2007). Selective pressurized liquid extraction for multi-residue analysis of organochlorine pesticides in soil. Journal of Chromatography A, 1152, 247-253. doi:10.1016/j.chroma.2007.02.076.

Koch, P. L., Stier, J. C., Senseman, S. A., Sobek, S., \& Kerns, J. P. (2013). Modification of a commercially-available ELISA kit to determine chlorothalonil and iprodione concentration on golf course turfgrass. Crop Protection, 54, 35-42. doi:10.1016/j.cropro.2013.07.017

Kumar, B., Kumar, S., Gaur, R., Goel, G., Mishra, M., Singh, S. K., Sharma, C. S. (2011). Persistent organochlorine pesticides and polychlorinated biphenyls in intensive agricultural soils from North India. Soil \& Water Research, 4, 190-197.

Leitão, S., Cerejeira, M. J., Van den Brink, P. J., \& Sousa, J. P. (2014). Effects of azoxystrobin, chlorothalonil, and ethoprophos on the reproduction of three terrestrial invertebrates using a natural Mediterranean soil. Applied soil ecology, 76, 124-131. doi: 10.1016/j.apsoil.2013.12.013.

Nakata, H., Kawazoe, M., Arizono, K., Abe, S., Kitano, T., Shimada, H., Ding, X. (2002). Organochlorine pesticides and polychlorinated biphenyl residues in foodstuffs and human tissues from china: Status of contamination, historical trend, and human dietary exposure. Archives of Environmental Contamination and Toxicology, 43, 473-480. doi:10.1007/s00244-002-1254-8.

Ons, L., Bylemans, D., Thevissen, K. and Cammue, B., 2020. Combining Biocontrol Agents with Chemical Fungicides for Integrated Plant Fungal Disease Control. Microorganisms, 8(12), p.1930.

Pimentel, D. (2009). Pesticides and pest control. In: Integrated pest management: innovationdevelopment process (pp. 83-87). Springer, Dordrecht.

Samuels, G. J. (2006). Trichoderma: Systematics, the Sexual State, and Ecology. Phytopathology. 96 (2): 195-206. doi:10.1094/PHYTO-96-0195. ISSN 0031-949X. PMID 18943925.

Shi, X. Z., Guo, R. J., Takagi, K., Miao, Z. Q., \& Li, S. D. (2011). Chlorothalonil degradation by Ochrobactrum lupini strain TP-D1 and identification of its metabolites. World Journal of Microbiology and Biotechnology, 27(8), 1755-1764. doi: 10.1007/s11274-010-06310 . 
US EPA, 1999. Reregistration Eligibility Decision for chlorothalonil.

Vinale, F., Sivasithamparam, K., Ghisalbertic, E.L., Marraa, R.S., Wooa, L., and Loritoa, M. (2007). Trichoderma plant pathogen interactions, Soil Biol Biochem. 40, 1-10.

Wang, G., Liang, B., Li, F., \& Li, S. (2011). Recent advances in the biodegradation of chlorothalonil. Current Microbiology, 63(5), 450-457. doi: 10.1007/s00284-011-0001-7.

Woo, S.L., Ruocco, M., Vinale, F., Nigro, M., Marra, R., Lombardi, N., Pascale, A., Lanzuise, S., Manganiello, G. and Lorito, M., 2014. Trichoderma-based products and their widespread use in agriculture. The Open Mycology Journal, 8(1), 71-126.

Yu, S., Wages, M. R., Cobb, G. P., \& Maul, J. D. (2013). Effects of chlorothalonil on development and growth of amphibian embryos and larvae. Environmental Pollution, 181, 329-334. doi:10.1016/j. envpol.2013.06.017

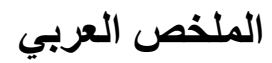

$$
\begin{aligned}
& \text { توافق عزلات الترايكوديرما مع مبيد الفظريات الكلوروثالونيل للمكافحة المتكاملة للأمراض } \\
& \text { محمد علوي سليم *, رمضان أبو بكر*, محمد زكي الثناوي** و جمال عانشور أحمد ** }
\end{aligned}
$$

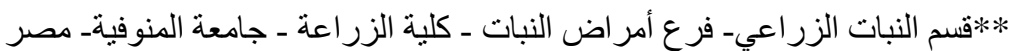

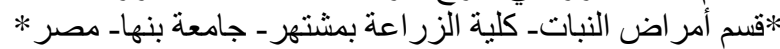

تم استخدام مبيدات الفطريات بنجاح لإدارة أمر اض النباتات المختلفة في جميع أنحاء العالم. وفقًا للاهتمامات البشرية و البيئية المختلفة كان إلزاميًا الحد من استخدام مبيدات الفطريات. يعتبر التكامل بين عامل المكافحة الحيوية ومبيدات الفطريات احد الخيار ات المهمة. للحصول على إمكانات أكثر فعالية، من المفضل أن يكون (Trichoderma) عامل المكافحة الحيوية متحملاً أو منو افقًا مع مبيد الفطريات المرغوب استخدامه. في هذه الدراسة تم قياس حساسية 11

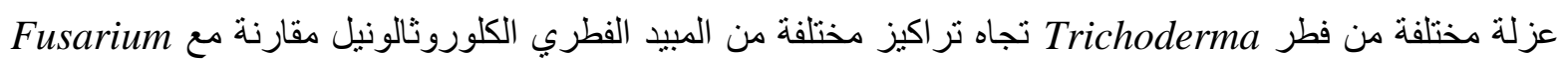
Trichoderma و اكتساب هذه العزلات للمقاومة تجاه الكلوروثالونيل. أظهرت النتائج أن جميع عز لات مئرئ المختبرة تتبط بشكل إيجابي نمو الفطر Fusarium culmorum في المعمل. أظهرت النتائج المتحصل عليها أن كلا من عز لات Fusarium culmorum و كانت حساسه ولم يتم تسجيل أي قدره علي تحمل الكلوروثالونيل. بعد استخدام تقنية الاقلمة، أظهرت النتائج أن قدرة تحمل جميع عزلات Trichoderma المختبرة تجاه الكلوروثالونيل قد ازدادت بشكل معنوي. وبالتالي، يمكن استخدام إمكانية اكتساب الترايكوديرما للمقاومة تجاه الكلوروثالونيل للإدارة المتكاملة للأمر اض. 